\title{
ECONOMIC TRANSFORMATION OF POST-COMMUNIST SMALL TOWNS: CASE STUDY OF THE LOWER SPIŠ REGION, SLOVAKIA
}

\author{
Ladislav NOVOTNÝa ${ }^{\mathrm{a}}$, Marián KULLA ${ }^{\mathrm{a}}$, Loránt PREGI ${ }^{\mathrm{a}}$, Stela \\ CSACHOVÁa
}

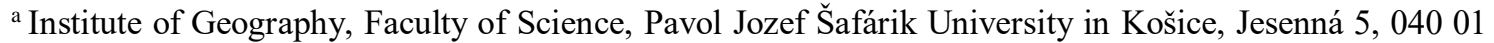

Košice, ladislav.novotny@upjs.sk, marian.kulla@upjs.sk, lorant.pregi@upjs.sk, stela.csachova@upjs.sk
\end{abstract}

Cite this article: Novotný, L., Kulla, M., Pregi, L., Csachová, S. (2019). Economic transformation of postcommunist small towns: Case study of the Lower Spiš region, Slovakia. Deturope. 11(1), 21-41.

\begin{abstract}
The aim of this paper is to examine how small towns have tackled the economic transformation in the postcommunist period. It aims to contribute to the comprehensive research of post-communist transformation at different hierarchic levels of settlement system. The study is spatially focused on the Lower Spiš region in Eastern Slovakia as it includes various kinds of small towns at relatively small area. Based on data provided by population censuses in 1991, 2001 and 2011, we assess development of economic performance of the towns by number of jobs, sectoral structure of jobs, ability to provide jobs for local economically active population, and spatial extent of commuting zones. The results prove that post-communist small towns remained important subregional centers of employment and commuting in general. They sustain even though some of them were affected by the recession of industrial sector and their economic base was established or substantially supported by the socialist industrialization. The growth of small towns' economic importance was recorded in the proximity of the major regional town - Spišská Nová Ves, mainly thanks to decentralization of economic activities.
\end{abstract}

Keywords: small towns, Slovakia, Lower Spiš, post-communist, economy, commuting

\section{INTRODUCTION}

The post-communist period brought about radical transformation of whole society in many attributes in the Central and Eastern European countries. That mirrored in urban and rural areas and led to the intensive research of post-communist transformation of urban (e.g., Enyedi 1998, Sailer-Fliege 1999, Tsenkova 2006, Sýkora \& Bouzarovski 2011, Navrátil et al., 2018, Balizs \& Bajmócy 2018, Kunc et al. 2018) and rural (e.g., Bański 2003, Spišiak et al., 2008, Spišiak 2011, Zubriczký 2011, Wójcik 2013, Kebza 2018) areas. Less attention, particularly in Slovakia, has been paid to research of small towns - the settlements integrating urban and rural features. While in other Central European countries there are certain research studies dealing with them (e.g., Zuzanska-Zysko 1999, Vaishar \& Zapletalová 2009, Kantor-Pietraga et al. 2012, Vaishar et al. 2012, Pirisi \& Trócsányi 2015, Czapiewski, Bański, \& Górczyńska 2016, Filipović, Kokotić Kanazir, \& Drobnjaković 2016, Vaishar, Zapletalová, \& Nováková 2016), the topic has been marginal in Slovakia. 
The aim of the paper is to assess how small towns have tackled with economic transformation in the post-communist period on the example of the Lower Spiš region as it contains various kinds of small towns at relatively small area. Prior to small towns' analysis, the theoretical, methodological and historical backgrounds are introduced. Development of economic performance of small towns is assessed by the set of indicators - number of jobs, sectoral structure of jobs, ability to provide jobs for local economically active population, and spatial extent of commuting zones. The paper has the ambition to fill the gap in the Slovak research of small towns in Central Europe to contribute with knowledge on post-communist transformation of settlement system in Central and Eastern European countries.

\section{TERMINOLOGY AND THEORETICAL FRAMING}

The term of a town varies in definition, in geography even more ambiguous is the term of a small town. For comprehensive overview of approaches to the terms see Novotný et al. (2016) in Slovakia or for other post-communist Central European countries Pirisi et al. (2015). In order not to bewilder in using certain settlement terminology, the paper uses the following terms.

A settlement is generally referred to a community in which people live. It is mostly used for rural or urban settlement to denote the historical context implying the preceding forms prior the municipality. A term municipality is used after the settlement gains the administrative function. Municipality, as a local administrative unit, can be either of rural or urban character. It is also quite common to denote rural municipality with a term village, though not much preferred in Slovak geographical vocabulary. A town is an urban settlement historically associated with privileges or later with a status being granted by a ruler. A city is obviously larger in size and functions than a town and is usually referred to urban municipality exceeding 100,000 inhabitants.

The researched municipalities fall under the set of economic and population criteria. Research units (fig. 1) include towns up to 10,000 inhabitants and selected historical towns that despite losing their status played significant role in regional economy by the end of the socialist era. We call them "small towns" although they do not have to be necessarily granted a formal status of town at present. Thanks to this selection criterion, the largest rural municipality is intended to be included in the research. 
This paper is geared to small towns` economic transformation. We use the term postcommunist economic transformation, even though the Central European countries more often prefer the term post-socialist in synonymous understanding.

\section{DATA AND METHODS}

While there are many sources on data on economic structure and performance at national and regional scale, research in this field tackles very limited sources of data at local level. That is why we employed data published as Population census results for censuses in 1991, 2001 and 2011 (SOSR 1991, 2001a, 2011a). These data do not provide information on the wages or the value of local production, but provide details on local economically active population, i. e. number of employed by economic sector, basic information on commuting, number of unemployed, women at maternal leave. More detailed data on commuting at the local level for each of the three latest population censuses were published in special publications Outcommuting and in-commuting (SOSR 1994, 2001b and 2011b). Despite certain differences resulting from minor changes in methodologies, political and social situation, as well as general willingness of population to participate in population censuses, we consider employed data to be the most comprehensive, comparable and reliable to analyse the economic transformation at the level of individual municipalities in Slovakia. To emphasize results of transformation process and to gain better readability of figures, some graphic interpretations of results are provided only for the 1991 and 2011 censuses.

Evaluating the data from population censuses (SOSR 1991, 2001a, 2011a) on population structure by economic activity, sector of economic activity, and on commuting to work (outgoing and ingoing) by economic sector, enables us to examine the economic transformation of chosen municipalities. Number of jobs occupied by individuals with permanent address in given municipality ("number of jobs for locals") is estimated by deducting number of out-going commuters from total number of economically active people residing in given municipality. For number of economically active individuals employed in a town of residence expressed as percentage of total number of economically active individuals (including those commuting to other municipalities) we use the term "local demand satisfaction rate" meaning the ability of a municipality to provide jobs for its own economically active population (to satisfy its demand for jobs). Total number of jobs in each analysed municipality is estimated as a sum of number of jobs for locals and number of commuters to work to given municipality. These data do not provide detailed information on character of jobs (full-time or part time, temporal or 
permanent), but the estimated data for 1991, 2001 and 2011 are considered sufficient to mutually compare the municipalities and to record their development trends during postcommunist period.

Analogically, evaluating the data on sectors of economic activity of population and commuters, numbers of jobs by economic sectors in 1991, 2001 and 2011 are estimated for each municipality, what enables us to assess changes of the importance of individual sectors in the local economy. These estimations can be affected by certain distortions, which stem from small differences in categorization of economic activities in individual censuses, and also between categorization of employees in given municipalities and commuters. Thus, a category "education and health care" also includes employees in culture in 1991 and employees in public administration in 2011. A category "market and other services" also includes commuters with unidentified economic sector. Nevertheless, commuters with unidentified economic sector can have only minor impact on total numbers and should not significantly affect identified overall trends.

The jobs that were identified in the municipalities for own economically active population include sole traders (proprietorships) who are registered in the municipality, but may perform the work elsewhere. There may be analogically some sole traders working in municipalities but not being counted in the statistics as it does not record their real place of work. This fact may also affect overall results, but it is not possible to get more properly adjusted information due to the character of available statistical data.

The data on commuting at the level of individual municipalities from the three latest population censuses (SOSR 1994, 2001b and 2011b) were used to outline changes in spatial extent of commuting zones of analysed municipalities reflecting their changing role in regional economies. Data are considered reliable but the level of detail is limited. The commuting flow from municipality to municipality (in one direction) is reported only when the total number of commuters to work together with pupils and students commuting to schools is 10 persons at least. Smaller flows are not reported separately, but as "other commuters within the district/from other districts/from abroad". That is why these flows are not visualised in the maps as flows although the commuters are included in the net commuting balance of each municipality. Despite these limitations, this date source is the most detailed available for all municipalities and sufficient to outline general development trajectories. 


\section{Spatial frame}

The Spiš region is located in the north-western part of Eastern Slovakia and its northern part exceeds to Poland with very small area. It used to be an administrative county in Hungarian Kingdom from the 11th till the 20th century. The region is surrounded by mountain ranges so its border that shaped already by the early 14th century persisted almost unchanged until collapse of Austria-Hungary in 1918 (Novotná, 2017). The region was historically characterized by multi-ethnic and even multi-confessional population (Šoltés 2009, Benža et al. 2015), what contributed to strong regional identity which remains still preserved, although the region has not been an individual territorial administrative unit since the formation of Czechoslovakia after the World War I. Comparing spatial extent of Spiš as a historical region to the current administrative division, the region covers area of districts (LAU1) Gelnica and Spišská Nová Ves within the Košice county (NUTS III Košický kraj), and Poprad, Kežmarok, Levoča and Stará L'ubovňa in the Prešov county (NUTS III Prešovský kraj). Less than 200 km² is located in Poland (fig. 1). Majority of population and economic activities are concentrated into the basins of the Hornád and Poprad rivers. Both flow from western part of the region, the Poprad river flows north-eastwards and the Hornád river south-eastwards, gaining lots of tributaries. They shape the inner division of the region into Upper Spiš (the basin of the Poprad including the valley of the Dunajec river) and Lower Spiš (the basin of the Hornád including the valley of the Hnilec river, the largest tributary of the Hornád within the region).

The historical region of Spiš was characterised by unique multi-layer structure of territorial administration and multiple economic transformation over the centuries. This led to development of specific hierarchy in the regional settlement system evidenced in higher concentration of small towns and lack of distinct regional metropolis. In Slovakia, there are now 21 municipalities with population from 2,000 to 5,000 having recently been granted a status of town and 5 of them are situated in the Spiš region. There are also many municipalities with comparable and even higher number of inhabitants that are considered rural since they have not been granted the status of town, including the largest rural municipality in Slovakia with population nearing 9,000 (Smižany) by the end of 2017 in the region. Some other municipalities were granted a town status in the distant past but lost it in latter periods.

The research is spatially focused on the Lower Spiš region as it contains historical centres of both secular and ecclesiastical power, medieval towns of all kinds (royal, mining, royal 
mining, craft and market towns, towns pawned to Poland) as well as municipalities that thrive into towns during socialist industrialization. All these towns are now at different positions in the regional settlement hierarchy. The Lower Spiš region spatially corresponds with the Spišská Nová Ves functional urban region (FUR) delimited by Bezák (2000) on a basis of data on commuting from the 1991 population census. It means that the region was internally coherent and externally relatively enclosed by the end of the socialist period when daily labour commuting considered. Spatial focus on smaller territory allows us for more detailed analysis at the level of individual municipalities.

Figure 1 Situation of the researched region

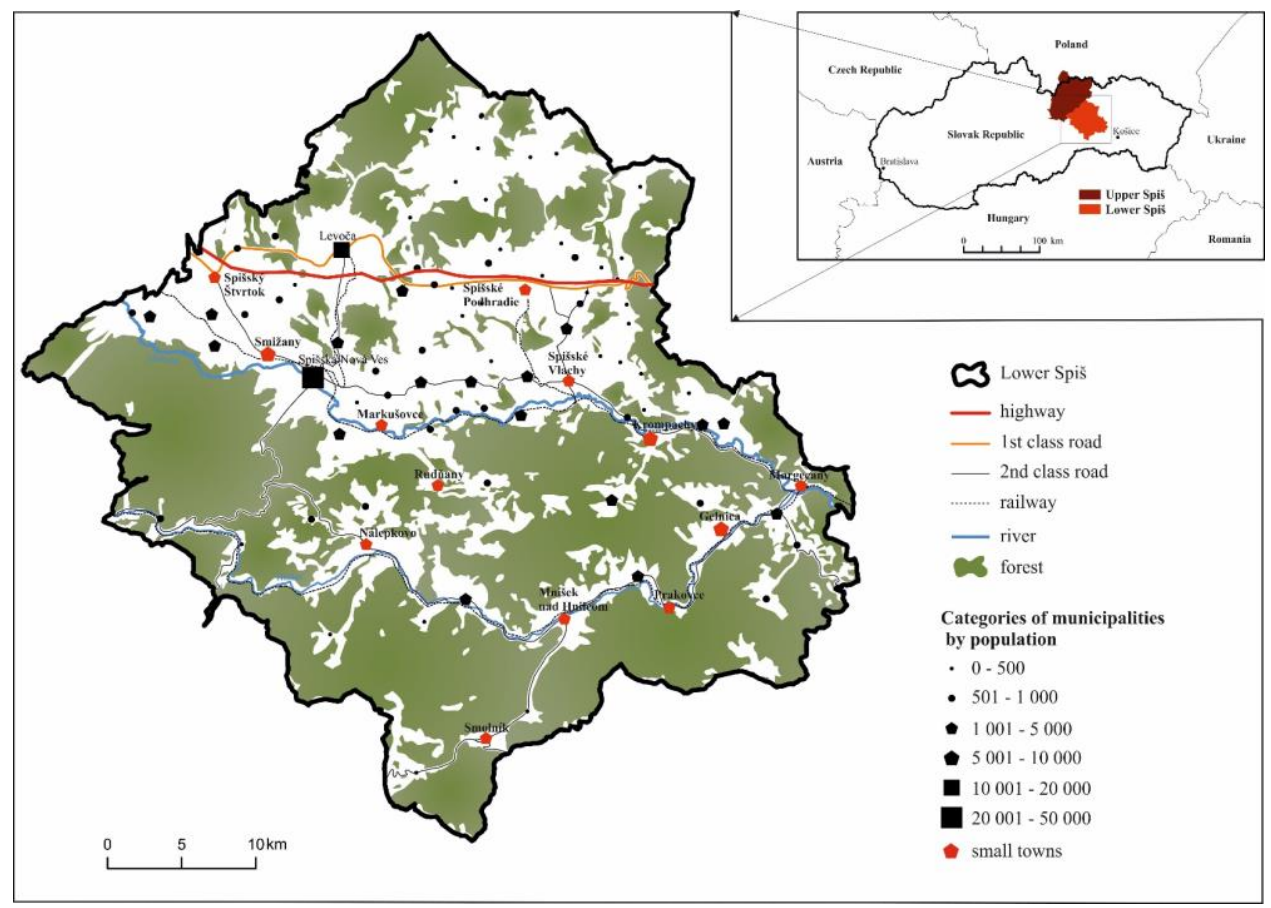

Source: ESRI Data (2018)

\section{Historical background}

In the past, Lower Spiš belonged to the economically most developed regions in the territory of present-day Slovakia. German immigration to the region became massive after the Tartar invasions into Hungary in 1241-1242, when Hungarian King Bela IV directly invited German settlers to contribute to economic and social development and introduced very accommodating policies towards them (Gabzdilová \& Olejník, 1998, Lengová, 2012). Rich sacral and secular privileges that were granted to municipalities with German settlements induced development of crafts and trade in several medieval towns for the next centuries (Levoča, Spišské Vlachy, Spišské Podhradie, Spišský Štvrtok). 
Mining and related industries contributed to economic development of the region as a whole and particularly to certain towns (Gelnica, Smolník, Krompachy, Rudňany, Spišská Nová Ves, Nálepkovo, Mníšek nad Hnilcom). But by the end of the 19th century, depletion of mineral (predominantly ore) deposits led to closure of mines and downturn of related industries. This process was more intensified after the breakdown of Hungary, which meant the loss of traditional markets for industrial enterprises and trade centers in the territory of today's Hungary and southern Poland (Jančura, 2012, Spišiak \& Kulla, 2009).

In newly established Czechoslovakia in 1918, Lower Spiš became peripheral and economic development in the region was recorded only alongside the main railways connecting East Slovakia with industrial Silesian region and Prague in the western part of the republic.

Turbulent history and changing multi-level administrative organization strengthened administrative function of some towns (Levoča, Spišská Nová Ves, Gelnica, Spišské Podhradie, Spišské Vlachy, Markušovce1), what stimulated their economic growth (cf. Žifčák, 2004; Jurková, 2013a,b; Rábik, Labanc, \& Tibenský, 2013).

While mining and ore processing had a rich tradition in the region, the development of other industries depended mostly on the socialist industrialization after the Second World War. In some cases, even the mining experienced revival thanks to generous state subsidies. Within the region, majority of socialist enterprises were located in Spišská Nová Ves (mainly woodworking, food and textile industries) but some were located even in smaller towns and other municipalities, partly in line with the tradition of ore processing. These towns became important industrial hubs, but their economic base was built on a small number (often only one) of large industrial enterprises. Within the researched region, this is the most case of Krompachy (ore processing and electro-technical industry), Rudňany (ore processing), Prakovce (armament industry), less in Gelnica (engineering industry) and Spišské Podhradie (travertine processing). In Smolník, employment increased in the cigar-producing factory which was established already in the 18th century, similarly distillery in Levoča. As a consequence of collectivization and the establishment of large enterprises in the primary sector of economy, some municipalities became centres of agriculture and/or forestry (Mníšek nad Hnilcom, Nálepkovo, Smižany, Spišské Vlachy, and Spišský Štvrtok). However, neither agriculture nor forestry were able to provide the number of jobs comparable with the industrial sector. So, these

\footnotetext{
${ }^{1}$ Markušovce as a municipality never had important administrative function, but it was the seat of powerful Mariassy family for centuries so it indirectly but considerably influenced the development in the region.
} 
municipalities did not become important centres of employment within the region and they lost importance in comparison with pre-socialist era. The tertiary sector in the socialist era was generally underdeveloped. The only exception among the considered municipalities was Margecany, the railway junction, where the number of jobs was provided in the railway transportation (Spišiak and Kulla 2009).

\section{RESULTS AND DISCUSSION}

\section{The number of jobs and their sectoral structure}

At the turn of socialist and post-communist era, Krompachy was the most important centre of employment among the analysed small towns. The town with 8,000 inhabitants and less than 4,000 economically active inhabitants provided over 5,500 jobs (fig. 2), most of them in industry and construction (fig. 3). Very similar situation, but with about half of the number of jobs was in Rudňany and Prakovce. In Smolník, the sectoral structure of jobs was alike (fig. 3), but the number of jobs was considerably smaller (fig. 2). More than 2,000 jobs were provided in Gelnica (fig. 2) but sectoral structure was much more diversified (fig. 3).

By 2001, almost all communities recorded decrease in the number of jobs (tab. 1) as a trend related to post-communist economic transformation. In emerging market economy and shifting trading relations from the East to the West, many socialist enterprises bankrupted, or were at least forced to reduce an overemployment considerably. The largest decrease in the number of jobs, exceeding significantly general trends in the region, was recorded in Rudňany, Krompachy and Prakovce, the towns with largest socialist industrial estates (cf. Spišiak and Kulla 2009) and with relatively monofunctional - industrial character by 1991. Krompachy and Prakovce lost about a third of jobs during that decade, Rudňany even over two thirds of jobs so the town utterly lost its function of regional centre of employment. On the other hand, Gelnica, Nálepkovo, Spišské Podhradie and Spišské Vlachy - the municipalities with relatively diversified sectoral structure of jobs (fig. 3) recorded only insignificant loss (lesser than 10\%) of jobs.

In the following period (2001-2011) the intensity of loss of jobs was lower. Majority of small towns continued to lose the jobs, rather those industrial. However, mainly smaller centres of employment that were not industrialized during the socialist era (Spišské Vlachy, Spišský Štvrtok, Markušovce) recorded increase in the number of jobs. Stabilization was recorded also 
in Krompachy, where foreign direct investment by Panasonic in 2000 (1250 employees in 2008) helped to compensate loss of jobs from other larger industrial enterprises. However, for the sake of Global economic crisis the company began with gradual redundancy and finally left Krompachy in 2015 (TASR 2014).

Table 1 Development of number of jobs in the small towns of Lower Spiš $(1991,2001,2011)$

\begin{tabular}{|c|c|c|c|c|c|c|c|}
\hline \multirow[b]{2}{*}{ municipality/region } & \multirow{2}{*}{$\begin{array}{l}\text { population } \\
\text { in } 2001\end{array}$} & \multicolumn{3}{|c|}{ number of jobs } & \multicolumn{3}{|c|}{ growth index number in $\%$} \\
\hline & & 1991 & 2001 & 2011 & $\begin{array}{c}1991- \\
2001\end{array}$ & $\begin{array}{r}2001- \\
2011\end{array}$ & $\begin{array}{c}1991- \\
2011\end{array}$ \\
\hline Gelnica & 6404 & 2331 & 2144 & 1828 & 92,0 & 85,3 & 78,4 \\
\hline Krompachy & 8812 & 5505 & 3584 & 3570 & 65,1 & 99,6 & 64,9 \\
\hline Margecany & 2035 & 1144 & 837 & 540 & 73,2 & 64,5 & 47,2 \\
\hline Markušovce & 3243 & 649 & 525 & 547 & 80,9 & 104,2 & 84,3 \\
\hline Mníšek nad Hnilcom & 1691 & 427 & 360 & 320 & 84,3 & 88,9 & 74,9 \\
\hline Nálepkovo & 2626 & 600 & 543 & 449 & 90,5 & 82,7 & 74,8 \\
\hline Prakovce & 3415 & 2331 & 1611 & 1006 & 69,1 & 62,4 & 43,2 \\
\hline Rudňany & 3196 & 2438 & 765 & 392 & 31,4 & 51,2 & 16,1 \\
\hline Smižany & 7847 & 839 & 1267 & 1423 & 151,0 & 112,3 & 169,6 \\
\hline Smolník & 1299 & 795 & 565 & 263 & 71,1 & 46,5 & 33,1 \\
\hline Spišské Podhradie & 3780 & 1384 & 1285 & 1049 & 92,8 & 81,6 & 75,8 \\
\hline Spišské Vlachy & 3518 & 933 & 904 & 909 & 96,9 & 100,6 & 97,4 \\
\hline Spišský Štvrtok & 2273 & 466 & 347 & 402 & 74,5 & 115,9 & 86,3 \\
\hline small towns & 50139 & 19842 & 14737 & 12698 & 74,3 & 86,2 & 64,0 \\
\hline Levoča & 14366 & 5866 & 5029 & 4490 & 85,7 & 89,3 & 76,5 \\
\hline Spišská Nová Ves & 39193 & 22416 & 19242 & 17884 & 85,8 & 92,9 & 79,8 \\
\hline Lower Spiš region & 156237 & 56939 & 48098 & 47669 & 84,5 & 99,1 & 83,7 \\
\hline
\end{tabular}

Source: own elaboration based on SOSR (1991, 1994, 2001a, 2001b, 2011a, 2011b)

The only small town in the region that recorded increase in the number of jobs during the 19912001 period and even in the 2001-2011 period, though with less intensity, was Smižany. The largest municipality in Slovakia not having the status of town (about 9,000 inhabitants) was administratively annexed to the Spišská Nová Ves municipality by the end of socialist era, when the construction of prefabricated housing estate started to be built and spatially merged to Spišská Nová Ves. Based on local referendum Smižany regained administrative autonomy as soon as in 1990 (Šoltísová 2015). Construction and emerging decentralisation (suburbanisation) of population from Spišská Nová Ves caused Smižany's rapid increase of population (from about 4,000 in 1990 to about 8,000 in 2011) (cf. Novotný 2010, SOSR 2011). Rising number of inhabitants naturally led to increase in the number of jobs, particularly in market and services. This can be seen in sectoral structure of jobs in Smižany, where the proportion of jobs in market and services significantly rose among all analysed municipalities (fig. 3). 
Figure 2 Development of the number of jobs in small towns of Lower Spiš (1991, 2001, 2011)

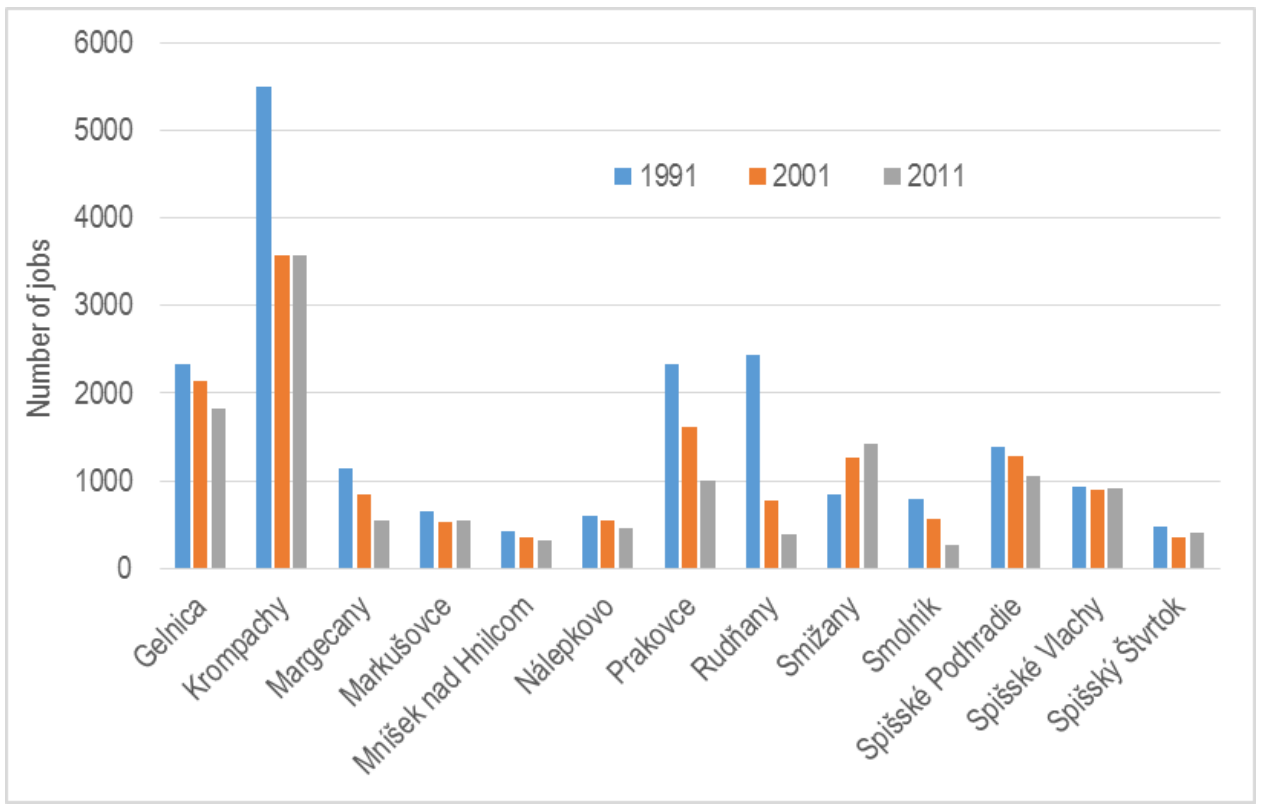

Source: own elaboration based on SOSR (1991, 1994, 2001a, 2001b, 2011a, 2011b)

The observations from Poland (Kantor-Pietraga et al. 2012) that industrial monofunctional small towns were the most negatively affected by the post-communist economic transformation are in concord with our observation that socialist industrial centres lost the largest number as well as proportion of jobs. The worst effect of the post-communist transformation was recorded in Rudňany, where the number of jobs decreased from 2438 in 1991 to 392 in 2011, meaning there were only $16 \%$ of jobs from 1991 retained to 2011 (tab. 1, fig. 2). Less than $50 \%$ of jobs retained in Smolník (33\%) and Prakovce (43\%).

The largest center of employment among analyzed small towns - Krompachy lost considerable number of jobs in industry and construction which was the most important sector in 1991, but due to stabilized or even increasing numbers of jobs in other sectors, overall loss was lower than in the abovementioned small towns. Krompachy retained $65 \%$ of the jobs in the 1991-2011 period and retained largest proportion of jobs in industry and construction among all analyzed small towns (over 25\%). The situation is similar in Gelnica, which unlike Krompachy had well diversified sectoral structure of jobs in 1991, and became a seat of restored district in 1996, what helped to increase the number of jobs in public administration (included to the category education and health care in fig. 3).

On the other hand, smaller centers of employment which were not considerably industrialized during the socialist era coped relatively well with the post-communist 
transformation as the numbers of jobs decreased less significantly. The best example is Spišské Vlachy, which retained over $97 \%$ of jobs, but considerably changed sectoral structure. Numbers of jobs in secondary and tertiary sectors increased at the expense of jobs in agriculture and forestry (fig. 3). Spišské Vlachy together with Spišský Štvrtok (86\%) and Markušovce (84\%) were the only small towns that retained higher proportion of jobs than the Lower Spiš region as a whole $(83.7 \%)$.

Special case is Smižany, where the number of jobs increased by 70\% during the 1991-2011 period, which can also be attributed to the decentralization of jobs (commercial suburbanization) from Spišská Nová Ves, but it is mainly caused by almost doubling the population size of the municipality.

The analysis also shows that the municipalities which have presently the status of town (Krompachy, Gelnica, Spišské Podhradie and Spišské Vlachy) coped generally better with the post-communist transformation, although the population size of smaller of them (Spišské Vlachy and Spišské Podhradie) is comparable or even smaller than some other municipalities not having the status of town (Prakovce, Markušovce, Rudňany, Nálepkovo). Even though all of them recorded certain drop of jobs, they remained valid regional centers of employment.

The number of jobs in the main regional urban center of Spišská Nová Ves (population almost 40,000) decreased from about 22,500 to less than 18,000 in 2011, which means the town retained $80 \%$ of jobs. The region's second largest town Levoča (15,000 inhabitants) retained $77 \%$ of jobs (decrease from 5,900 to 4,500). Both are presently seats of districts, although the position of Spišská Nová Ves is stronger in the hierarchy of regional public administration. Both towns had relatively well diversified sectoral structure of jobs even by the end of the socialist era. The relative decrease in the number of jobs in them was higher than in the whole region but stays smaller than in the largest industrial centers among the small towns (particularly Krompachy, Rudňany, Prakovce). 
Figure 3 Number and sectoral structure of jobs in small towns of Lower Spiš in 1991 and 2011

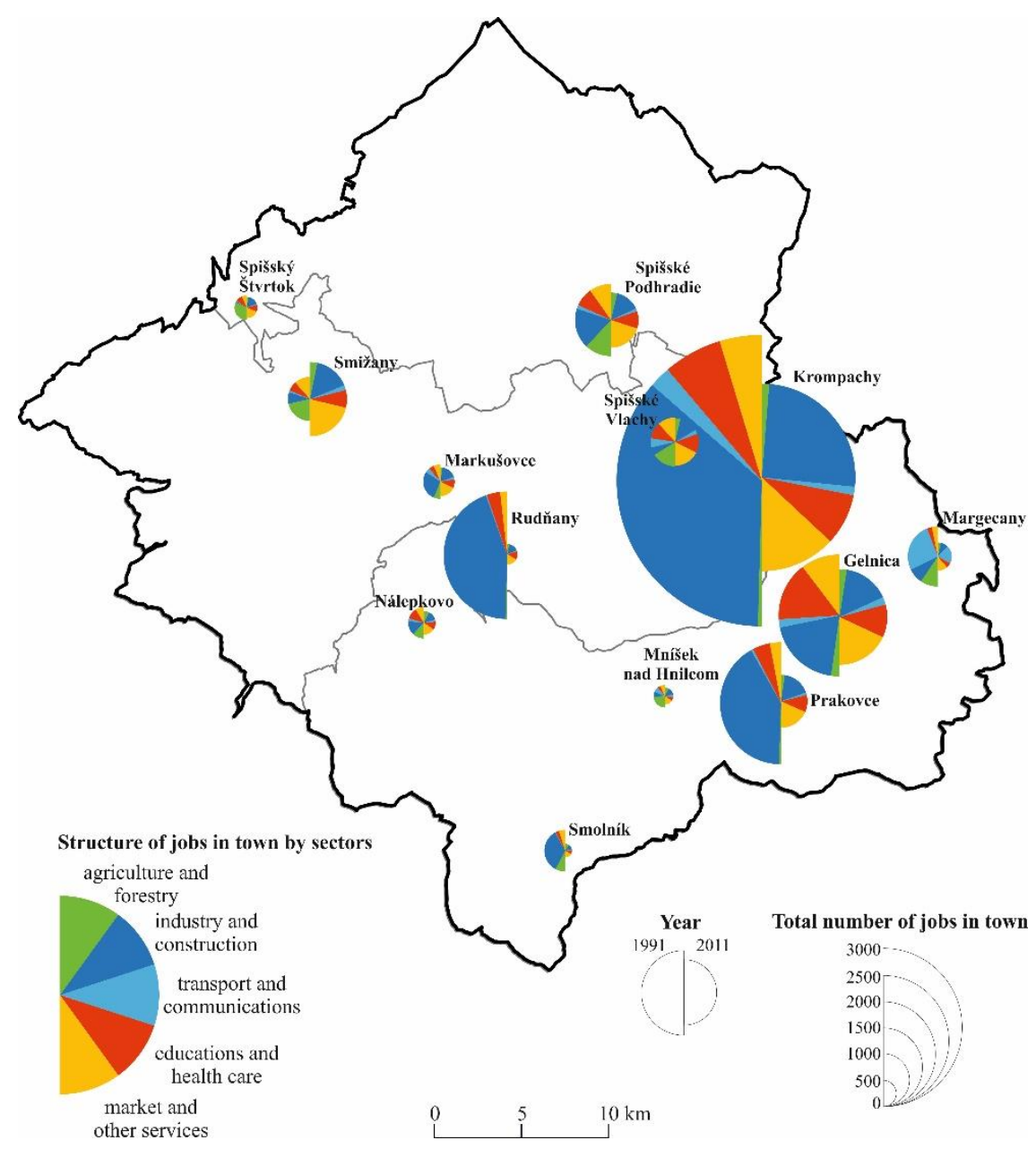

Source: own elaboration based on SOSR (1991, 1994, 2001a, 2001b, 2011a, 2011b)

The largest centres of employment at the end of the socialist period, whose economic base was based on one or limited number of socialist enterprises, lost the largest proportion of jobs. Some of them (Smolník, Rudňany) lost their position of regional centres of employment. Number of jobs in four towns (Krompachy, Prakovce, Rudňany and Smolník) where the proportion of jobs in industry and construction exceeded $50 \%$ of all jobs in 1991, lost more than $50 \%$ of jobs by 2011 (decrease from 11,069 to 5,231). On the other hand, the major regional town and centre of employment Spišská Nová Ves lost much lower proportion of jobs, nearing the proportion of loss of the region as a whole. Small historical towns not directly affected by the socialist industrialization (or rather negatively as they downturned in regional hierarchy of employment centres) recorded much less significant decrease in the number of jobs - by less than $15 \%$, from 8,773 in 1991 to 7,467 in 2011.

As indicated in tab. 2, in contrast to Spišská Nová Ves, the importance of small towns as regional centres of employment declined considerably during the post-communist transformation period. However, this was mainly caused by the loss of jobs in the small towns, 
the ones most industrialized during the socialist era. Although the number of jobs in the category of less industrialized towns decreased as well, it was smaller in comparison with the region as a whole, and so the proportion of jobs in these small towns even slightly increased. The most considerable increase in the proportion of jobs was recorded in the category of rural municipalities, which almost reached the proportion of jobs in the category of small towns in 2011.

Table 2 Proportion of the number of jobs in categories of municipalities of all jobs in the region

\begin{tabular}{lccc}
\hline \multirow{2}{*}{ category of municipalities } & \multicolumn{3}{c}{ proportion of all jobs in the region in \% } \\
\cline { 2 - 4 } & 1991 & 2001 & 2011 \\
\hline small towns & 34,8 & 30,6 & 26,6 \\
$\quad$ more industrialized small towns & 19,4 & 13,6 & 11,0 \\
$\quad$ less industrialized small towns $* *$ & 15,4 & 17,1 & 15,7 \\
Spišská Nová Ves (major regional town) & 39,4 & 40,0 & 37,5 \\
rural municipalities & 15,5 & 18,9 & 26,4 \\
\hline
\end{tabular}

Source: own elaboration based on SOSR (1991, 1994, 2001a, 2001b, 2011a, 2011b); *towns with the proportion of jobs in industry and construction exceeding 50\% of all local jobs in 1991 (Krompachy, Prakovce, Rudňany, Smolník); **all other small towns

The results indicate two simultaneous but opposing processes taking place in the region. On the one hand, Spišská Nová Ves strengthened its position among the largest centres of employment in the region, what was given by process of centralization of employment into the largest town, at the expense of medium sized and smaller communities. On the other hand, the relative decrease in the number of jobs in larger small towns and even in Spišská Nová Ves and Levoča was higher than the average for region as a whole, what indicates that decentralization of employment from towns (regardless if currently with status of town or historical) to rural communities is taking place.

At the same time, suburbanization that influences spatial redistribution of population in the region (Novotný 2010) seems to be responsible even for spatial redistribution of employment. This is seen particularly in Smižany which, besides rapid growth of population, recorded rapid growth in the number of jobs, and to a less extent Markušovce and Spišský Štvrtok located in the vicinity of Spišská Nová Ves.

All these processes were accompanied with considerable changes in the sectoral structure of jobs. These are connected with deindustrialization and tertiarization, the processes characteristic for post-communist transformation (cf. Domański 2011, Korec 2007, Popjaková 2008, Rusnák and Bystrická 2010). Thus the transformation affected the most socialist industrial centres and smaller centres of employment benefited from rather diversified sectoral structure of economy. The exceptions can be found in the southernmost part of the region. The historical mining towns in the western part of the Gelnica district were neither substantially 
industrialized during the socialist period, nor during the post-communist period suffering from unfavourable location and poor transport infrastructure. They were losing jobs continuously even in the post-communist era.

\section{Volume and spatial range of commuting}

Spatial pattern of commuting to small towns of Lower Spiš naturally reflects changes in the number of jobs. Nevertheless, there are certain general trends observable in the region that cannot be truly explained only by the changes in the number of jobs.

Spišská Nová Ves as a major commuting centre in the region concentrated commuting flows from almost all municipalities within the region by the end of the socialist era. Although majority of flows weakened and some even disappeared, the commuting flows to Spišská Nová Ves covered almost whole area of region also in 2011. The size of some flows from neighbouring communities increased, particularly in the case of Smižany, which indicates that the trend of suburbanization is still more related to the population rather than the economic activities.

Small towns in the region recorded significant change in the spatial pattern of commuting between 1991 and 2001 (fig. 4). The largest commuting centres lost the largest numbers of commuters, so the differentiation between analysed municipalities as centres of commuting diminished. Sharp drop was recorded in Rudnany - the second largest commuting centre in 1991, however much smaller in 2001.

The largest commuting centres from 1991 recorded also the most significant spatial shrinkage of the commuting zones on the one hand, while the spatial extent of commuting zones of Gelnica, Smižany, Spišské Vlachy, Spišské Podhradie or Margecany remained almost unchanged on the other hand. It confirms that the small towns whose economic base was rather smaller but not based only on socialist industry, coped much better with the early stage of the post-communist transformation.

The commuting flows seem to be integrated and spatially equally distributed across the region in 1991. In 2001, the split of commuting subsystem in the southern part of the region is noticeable. It refers to the valley of the Hnilec river which is enclosed by mountain ranges from all sides but the narrow area in the east, where Hnilec flows into the Hornád river. The split is even more apparent in 2011 (fig. 4). This is in line with observations by Bezák $(2000,2014)$ stating that while the Gelnica-Prakovce functional urban region (FUR) was more integrated with the Spišská Nová Ves FUR in 1991, in 2001 it already had more commuting interactions with the Košice FUR located to the south. In 1991 Gelnica and Prakovce were relatively equal 
centres creating the commuting core of the FUR, the role of Prakovce diminished and Gelnica became dominant in latter periods.

Despite rapid decline in the number of in-commuters and shrinkage of its commuting zone during the 1991-2001 period, Krompachy stabilized its position in the 2001-2011 period and became the most dominant commuting centre among analysed small towns. Former large industrial centres and commuting cores such as Prakovce, Rudňany or Smolník continued to decay and the last two mentioned lost their role as commuting centres at all (fig. 4). The shrinkage of commuting zones of the formerly larger commuting centres imply they lost the role of inter-regional commuting centres and became rather sub-regional. This is documented also by lowering the proportion of commuters not included in visualised commuting flows (fig. 4).

Figure 4 Transformation of spatial patterns of migration into the small towns of Lower Spiš $(1991,2001,2011)$
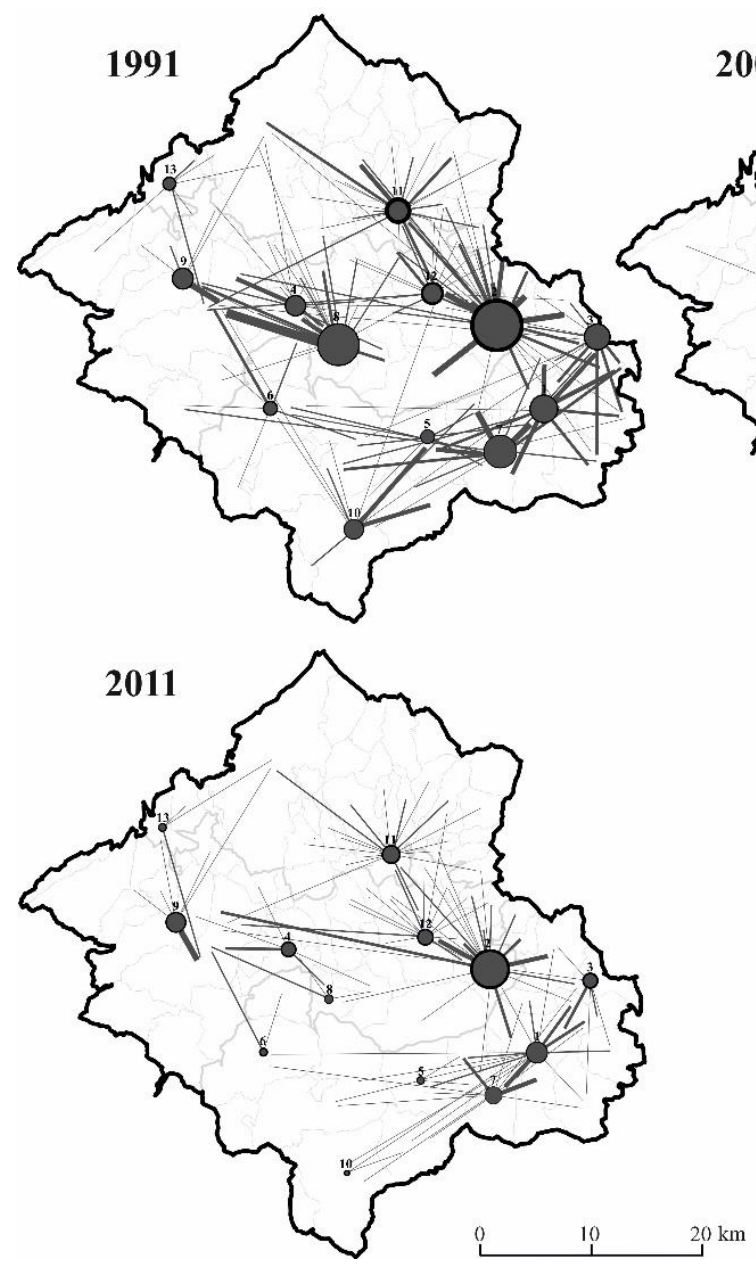

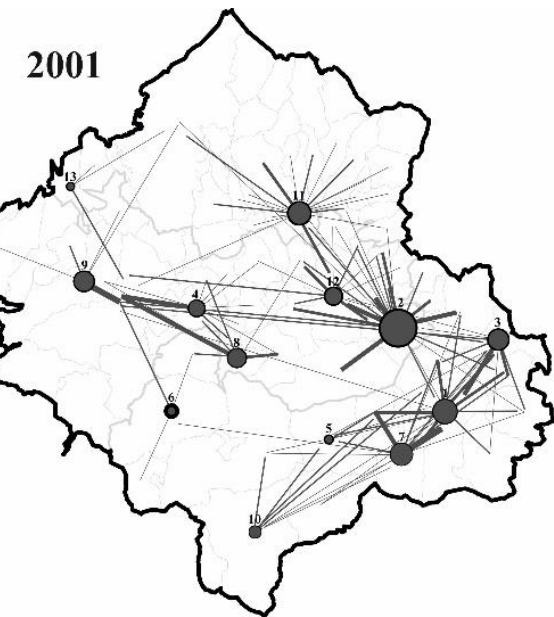

Number of commuters to town

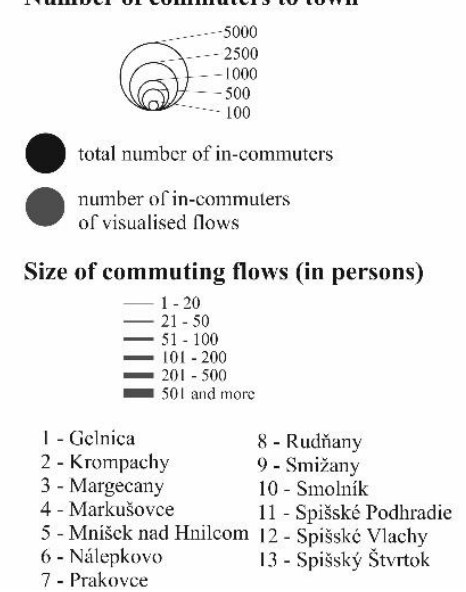

Source: own elaboration based on $\operatorname{SOSR}(1994,2001 b, 2011 b)$

Decline in importance of commuting centres went hand in hand in reduction of the ability to provide jobs for its own economically active population in majority of analysed small towns 
(fig. 5). In 1991, the highest ability to provide jobs for own population was recorded in the largest employment centres (Krompachy, Prakovce, Rudňany, Gelnica) but also in Smolník with relatively poor transport accessibility.

Figure 5 Local demand satisfaction rate in small towns of Lower Spiš (1991, 2001, 2011)

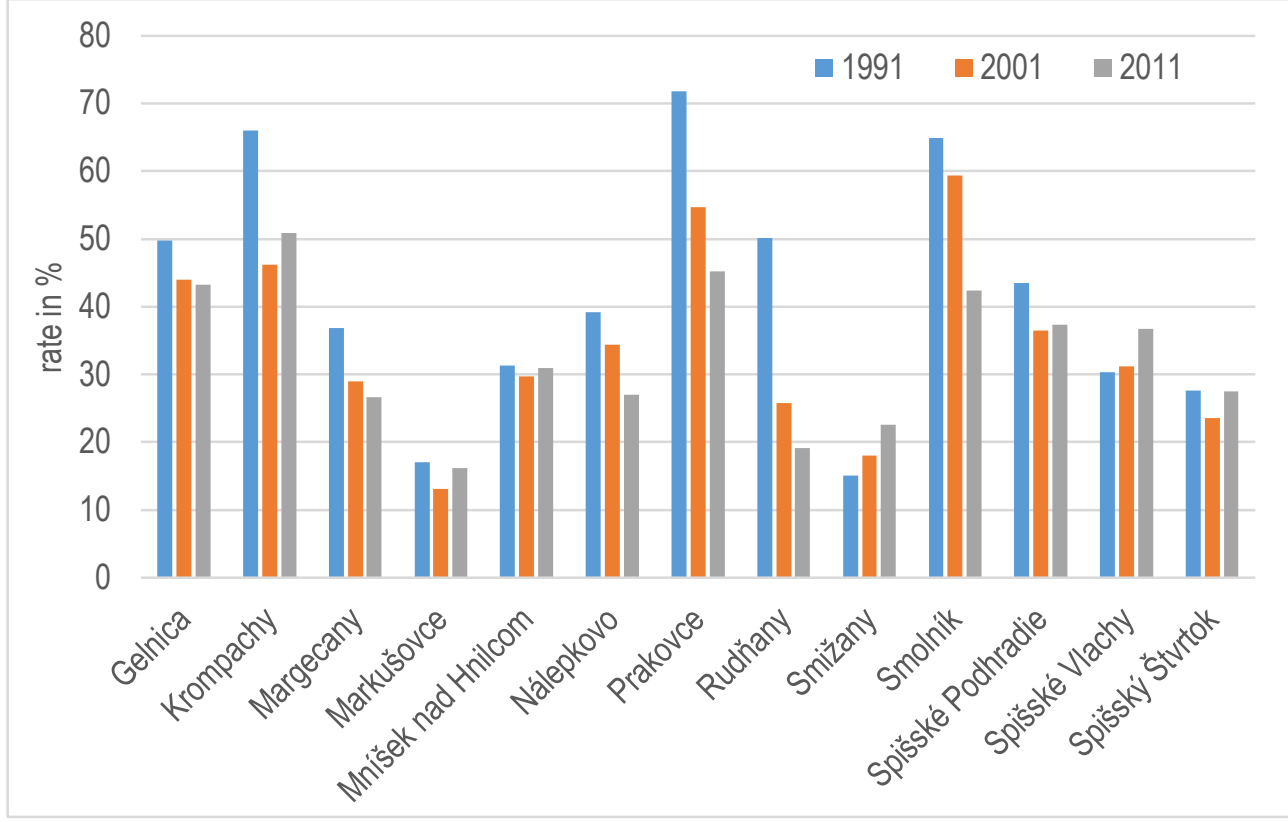

Source: own elaboration based on SOSR (1991, 1994, 2001a, 2001b, 2011a, 2011b)

By the 2001, the ability to satisfy own population's demand for jobs declined in all small towns apart from Spišské Vlachy and Smižany. These were the only towns that reached higher values in 2011 than in 1991. From the point of view of availability of jobs for local population it means they maintained the post-communist transformation most successfully. It is particularly interesting in the case of Smižany which recorded rapid growth of population over this period. After more considerable declines during the 1991-2001 period, the situation levelled off in majority of towns or even improved in some cases (Krompachy, Markušovce, Mníšek nad Hnilcom, Spišské Podhradie, Spišský Štvrtok). On the other hand, Prakovce, Rudňany and especially Smolník kept on further significant declining.

There is certain distortion between relatively stabilised or even improved ability of small towns to satisfy the local demand for jobs, and continuously declining numbers of jobs in these towns (cf. fig. 2 and fig. 5). This may be a result of two simultaneously ongoing processes. The first is the ageing of population what means that larger number of population is moving from the category of economically active to the category of pensioners than the number of moving from category of pupils and students into the category of economically active. This is accompanied by the emigration from the analysed towns, which has been described in detail at 
regional level by Novotný and Pregi $(2016$ a, b). It is based on the assumption that the number of economically active people in these small towns decreased, so the towns could satisfy larger proportion of economically active inhabitants even with the smaller number of jobs.

\section{CONCLUSION}

In this paper we sought to assess economic transformation of small towns in the Lower Spiš region during the post-communist era. The researched objects were towns up to 10,000 inhabitants and selected historical towns that lost the formal status of town, but played significant role in regional economy by the end of socialist era. Therefore, the analysed municipalities are termed "small towns" although not all of them are being granted a formal status of town at present.

The research is based on data from population censuses in 1991, 2001 and 2011 which allowed for in-depth analysis by variety of indicators applied from regional to local level. The results show that majority of small towns was negatively affected by the post-communist transformation and certain differences and regularities were identified.

In concord with rather general features of post-communist economic transformation in Central and Eastern-European countries, almost all small towns underwent the processes of deindustrialization and tertiarization. Therefore, the most significant decrease in the number of jobs was recorded in small towns whose economic base was built on one or a limited number of large industrial factories during the socialist era. The larger towns were partially able to compensate the loss of jobs in industry and construction by growing number of jobs in other sectors, particularly in retail and services. Small towns that were not industrialized during the socialist era have handled with the post-communist transformation much better. Majority of them recorded small decrease in the number of jobs, but the intensity of decrease was lesser than in the region as a whole. So the category of all small towns recorded clear downturn in the hierarchy of the centres of employment, due to former industrial towns, but towns that were rather omitted from the socialist industrialization even strengthened their hierarchic position in regional economic system.

Changes in spatial pattern of commuting to small towns partially reflect the decrease in the number of jobs. Commuting zones shrunk most in the industrial towns, particularly those where socialist industrialization maintained economic base established on mining tradition. Without state subvention in post-communist era, such economic base collapsed and historical mining small towns lost their status of sub-regional economic centers and commuting centers as well. On the other hand, commuting zones of small towns with smaller but well diversified economic 
base by the end of the socialist era maintained commuting zones almost unchanged or even expanded slightly.

The difference in the number of jobs and even the number of in-commuting employees between the category of the industrialized and not industrialized towns diminished during the period of observation.

The development of the spatial pattern of commuting into the small towns also indicated certain regional differentiation resulting from the orography of the territory. The commuting flows seem to be integrated and spatially equally distributed across the region in 1991. However, the separation of commuting subsystem in the southern part of the region was apparent in 2001 and particularly 2011. It is the valley of the Hnilec river enclosed by mountain ranges from all sides but the narrow area in the east, where Hnilec flows into the Hornád river and where the region is linked by road and railway with the Eastern Slovak major city of Košice.

It is generally possible to state that small towns remain important sub-regional centres of employment and commuting. It is so despite the recession in the industrial sector which affected the towns where economic base was established or substantially supported by the socialist industrialization. Historical small towns, particularly in remote peripheral areas in the southwest kept on economic decay, whereas the growth of economic importance was recorded in the proximity of the major regional town - Spišská Nová Ves, mainly owing to decentralization of economic activities.

\section{Acknowledgement}

This work was supported by grant VEGA 1/0395/17, and the Slovak Research and Development Agency grant under the contract No. APVV-15-0306.

\section{REFERENCES}

Balizs, D., Bajmócy, P. (2018). Rajka: The "Hungarian suburb" of Bratislava. TER ES TARSADALOM, 32 (3), 54-75.

Bański, J. (2003). Współczesne i przyszłe zmiany w strukturze przestrzennej obszarów wiejskich - wybrane zagadnienia. In Górza B., \& Guzika, Cz. (Eds), Rural Studies Vol 4. Współczesne przeobrażenia i przyszłość polskiej wsi. Studia Obszarów Wiejskich (pp. 11-25). Warszawa: IGiPZ, PAN.

Bašovský, O. (1995). Súčasný stav a prognóza urbánnej a regionálnej štruktúry Slovenska a ekonomická transformácia. Sborník České geografické společnosti, 100 (2), 78-91.

Benža, M., Kusendová, D., Majo, J., \& Tišliar, P. (2015). Národnostný atlas Slovenska. Bratislava: Dajama.

Bezák, A. (2000). Funkčné mestské regióny na Slovensku. Geographia Slovaca 15, Bratislava: Geografický ústav SAV.

Bezák, A. (2014). Funkčné mestské regióny na Slovensku v roku 2001. In Lauko, V. et al. (Eds.) Regionálne dimenzie Slovenska (pp. 169-198). Bratislava: Univerzita Komenského. 
Czapiewski, K., Bański, J., \& Górczyńska, M. (2016). The Impact of Location on the Role of Small Towns in Regional Development: Mazovia, Poland. European Countryside, 8(4), 413-426.

Domański, B. (2011). Post-socialism and transition. In. A. Pike et al (ed.): Handbook of Local and Regional Development (pp. 172-182). Routledge, 172-182

Enyedi, Gy. (1998). Transformation in Central European Postsocialist Cities, In Enyedi, Gy. (Ed.) Social Change and Urban Restructuring in Central Europe (pp. 9-34). Budapest: Akademiai Kiadó.

Filipović, M, Kokotić Kanazir, V., \& Drobnjaković, M. (2016). Small Towns in Serbia-The "Bridge" Between the Urban and the Rural. European Countryside, 8(4), 462-480.

Gabzdilová, S., \& Olejník, M. (1998). Nemecká menšina na Slovensku po roku 1918 so zameraním na oblast' Spiša. Človek a spoločnost', 1 (4), 21-25.

Jančura, M. (2012). Z histórie rudného baníctva na Spiši. Spišská Nová Ves (Banícky spolok Spiš). Retrieved from http://www.spisskanovaves.eu/fileadmin/snv/user_ upload/editor/banicky_spolok_spis/publikacie/banictvo_spis.pdf.

Jurková, V. (2013a). Prvé delenie Pol’ska a spišský záloh. In Chalupecký I. (Ed.), Z minulosti Spiša. Ročenka Spišského dejepisného spolku v Levoči (pp. 89-114). Levoča: Spišský dejepisný spolok.

Jurková, V. (2013b). Vojenské obsadenie Spiša a jeho návrat pod uhorskú správu v roku 1772. In Fabová, B., Jančura, M. (Eds.), Zbornik štúdií z 2. vedeckej konferencie mladých historikov (pp. 13-25). Košice: Univerzita Pavla Jozefa Šafárika.

Kantor-Pietraga, I., Krzysztofik, R., \& Runga, J. (2012). Kontekst geograficzny i funkcjonalny kurczenia się małych miast w Polsce południowej. Studia Ekonomiczne, 92, 9-24.

Kebza, M. (2018). The development of peripheral areas: The case of West Pomeranian Voivodeship, Poland. Moravian Geographical Reports, 26 (1), 69-81.

Kopačka, L. (2000). Deindustrialization and restructuring in a transition countries: Czech industry after ten years of transformation. Acta Facultatis Rerum Naturalium Universitatis Comenianae, Geographica, supplementum 2/II, 121-135.

Korec, P. (2007). Vplyv post-industriálneho štádia vývoja spoločnosti a globalizácie na regionálny rozvoj Slovenska. Geographia Cassoviensis, 1, 75-80.

Kunc, J., Tonev, P., Martinát, S., Frantál, B., Klusáček, P., Dvořák, Z., Chaloupková, M., Jaňurová, M., Krajíčková, A., Šilhan, Z. (2018). Industrial legacy towards brownfields: historical and current specifics, territorial differences (Czech Republic). Geographia Cassoviensis, 12 (1), 76-91.

Lengová, M. (2012). Z dejín obchodu na Spiši (15. - 17. storočie). Človek a spoločnost', 15(2), 9-25.

Navratil, J., Picha, K., Martinat, S., Nathanail, P. C., Tureckova, K., Holesinska, A. (2018). Resident's preferences for urban brownfield revitalization: Insights from two Czech cities. Land Use Policy, 76, 224-234.

Novotná, A. (2017). Svojrázny Spiš v starých dobrých časoch prekvital. Korzár Spiš online. Retreived from: https://spis.korzar.sme.sk/c/20670753/svojrazny-spis-v-starychdobrych-casoch-prekvital.html?ref=tab.

Novotný, L. (2010). Migračné procesy v migračne úbytkovom funkčnom mestskom regióne: empirický príklad FMR Spišská Nová Ves. Acta Geographica Universitatis Comenianae, 54, 247-263.

Novotný, L., \& Pregi, L. (2016a). Selektívna migrácia podl'a vzdelania v migračne úbytkových funkčných mestských regiónoch Spišská Nová Ves a Gelnica. Acta Geographica Universitatis Comenianae, 60 (2), 189-205. 
Novotný, L., \& Pregi, L. (2016b). Vplyv vnútroregionálnej migrácie a prirodzenej reprodukcie obyvatel'stva na zmeny jeho štruktúry podl'a religiozity. Geographia Cassoviensis, 10(1), 47-69.

Novotný, L., Csachová, S., Kulla, M., Nestorová-Dická, J., \& Pregi, L. (2016). Development Trajectories of Small Towns in East Slovakia. European Countryside, 8(4), 373-394.

Pirisi, G., \& Trócsányi, A. (2015). Between shrinking and blooming: the crossroad of small towns' urbanisation in Hungary. Annales Universitatis Paedagogicae Cracoviensis Studia Geographica, 8(1), 12-28.

Popjaková, D. (2008). Globálna versus postsocialistická transformácia priemyslu (na príklade Slovenska). Acta geographica Universitatis Comenianae, 51, 3-25.

Rábik, V., Labanc, P., \& Tibenský, M. (2013). Historická geografia. Trnava, Filozofická fakulta Trnavskej univerzity, $82 \mathrm{p}$.

Rusnák, J., \& Bystrická, S. (2010). Osobitosti vývoja sektorovej štruktúry na Slovensku po roku 1989. Geografický časopis, 62 (2), 165-178.

Sailer-Fliege, U. (1999). Characteristics of post-communist urban transformation in East Central Europe. GeoJournal, 49, 7-16.

Šoltés, P. (2009). Tri jazyky, štyri konfesie: Etnická a konfesionálna pluralita na Zemplíne, Spiši a v Šariši. Bratislava (Historický ústav SAV).

Šoltísová, E. (2015). Smižany dostali prívlastok „naj“ po nežnej revolúcii. Korzár Spiš online. Retrieved from: https://spis.korzar.sme.sk/c/7919048/smizany-dostali-privlastok-naj-poneznej-revolucii.html.

SOSR (1991). Results of the 1991 population and housing census. Bratislava: Statistic Office of Slovak Republic (SOSR). Available at: http://sodb.infostat.sk/sodb/eng/ 1991/format.htm.

SOSR (1994). Dochádzka do zamestnania, škôl a učenia (výsledky sčitania luudu, domov a bytov 1991). Bratislava: Statistic Office of Slovak Republic (SOSR).

SOSR (2001a). Results of the 2001 population and housing census. Bratislava: Statistic Office of Slovak Republic (SOSR). Available at: http://sodb.infostat.sk/sodb/eng/ 2001/format.htm.

SOSR (2001b). Dochádzka do zamestnania, škôl a učenia (výsledky sčítania obyvatel'ov, domov a bytov 2001). Bratislava: Statistic Office of Slovak Republic (SOSR).

SOSR (2011a). Results of the 2011 population and housing census. Bratislava: Statistic Office of Slovak Republic (SOSR). Available at: http://census2011.statistics.sk/.

SOSR (2011b). Dochádzka a odchádzka do zamestnania a školy (výsledky sčitania obyvatelov, domov a bytov 2011). Bratislava: Statistic Office of Slovak Republic (SOSR).

Spišiak, P. (2011). Výskum rurálnej krajiny v posttransformačnom období na Slovensku. Geographia Cassoviensis, 5(1), 93-99.

Spišiak, P., \& Kulla, M. (2009). Priemysel Dolného Spiša s dôrazom na podnik Embraco Slovakia Spišská Nová Ves. Geographia Moravica, 1, 71-83.

Spišiak, P., Feranec, J., Ot’ahel, J., \& Nováček, J. (2008). Transition in the Agricultural and Rural Systems in Slovakia after 1989. In Bański, J., \& Bednarek, J. (Eds.), Rural Studies, 15, Contemporary Changes of Agriculture in East-Central Europe, (pp.121-146). Warszawa: IGiPZ, PAN.

Sýkora, L., \& Bouzarovski, S. (2011). Multiple transformations: Conceptualising the postcommunist urban transition. Urban Studies, 49(1), 43-60.

Székely, V. (1995). Formovanie priemyselnej štruktúry Spiša v rokoch 1948-1985. Spiš v kontinuite času: zbornik z medzinárodnej vedeckej konferencie. Prešov: Universum, 329339. 
TASR (2014). Panasonic will close plant in Krompachy. The Slovak Spectator online. Retrieved from: https://spectator.sme.sk/c/20052167/panasonic-will-close-plant-inkrompachy.html.

Tsenkova, S. (2006). Beyond transitions: Understanding urban change in post-communist cities. In Tsenkova, V., \& Budic-Nedovic, Z. (Eds.), The urban mosaic of post-communist Europe, (pp. 21-50). Heidelberg: Physica-Verlag,

Vaishar, A., \& Zapletalová, J. (2009). Small towns as centres of rural micro-regions. European Countryside, 1(2), 70-81.

Vaishar, A., Št’astná, M., Vavrouchová H., Stejskal B., Hlisnikovský, L., Kniezková, T., Pákozdiová, M. (2012). Malá města - motory rozvoje jihomoravského venkova. Brno: Mendelova univerzita $v$ Brně.

Vaishar, A., Zapletalová, J., \& Nováková, E. (2016). Between Urban and Rural: Sustainability of Small Towns in the Czech Republic. European Countryside, 8(4), 351-372.

Wójcik, M. (2013). Przemiany społeczno-przestrzenne osiedli wiejskich. Studium przypadku Łódzkiego Obszaru Metropolitalnego. Łódź: Wydawnictwo Uniwersytetu Łódzkiego.

Zubriczký, G. (2011). Rurálna deprivácia na Gemeri. Geographia Cassoviensis, 5(1), 133-137.

Zuzanska-Zysko, E. (2005). Economic Transformation of Small Silesian Towns in the Years 1990-1999. Geographia Polonica, 78(1), 137-149.

Žifčák, F. (2004). Storočná vojna na spišský spôsob. Historia revue, 4(9-10), 7-10. 